\title{
Strenghtening Nigeria's Federalism for National Development
}

\author{
Blessing .E.N Thom-Otuya \\ Department of Political Science \\ Ignatius Ajuru University of Education \\ Port- Harcourt \\ Rivers State, Nigeria
}

\section{Doi:10.5901/mjss.2013.v4n5p27}

\section{Abstract}

Federalism is a form of government that is often adopted by countries with great diversity in geography, language, culture and religion. Western countries like: United States of America, Canada, Australia, Belgium, and India are adopting the Federal system of government. They are politically and economically stable. Federalism in Nigeria has been bedeviled by myriad of problems since it was introduced by the Macpherson Constitution in 1954. Nigeria's federalist concept has been distorted, consequently impacting negatively on her national development, political stability and economic growth. Federalism in Nigeria can be strengthened to facilitate national development, if her leaders can only allow each level of government to be autonomous. This paper is aimed at affirming the benefits of federalism; strengthen the practice of federalism in Nigeria and to contribute to her national development. The paper delves into the concept and evolution of federalism; took a critical look at the nature of Nigeria's federalism, its missing link, and using Kenneth C. Wheare's concept of federalism to strengthen federalism in Nigeria towards sustained national development. The paper recommended the followings as a panacea to strengthening federalism in Nigeria: States should be created due to their ability to sustain themselves, all levels of government should be coordinate and independent, creation of State Police, each state should have absolute control of her wealth and resources, strengthening of the Nigerian Constitution to reflect Wheare's concept of federalism, two party system should be imposed, and strengthening of the judiciary for independent and effective performance.

Key Words: Diversity, Nigeria, Federalism, National Development,

\section{Introduction}

Federalism is an institutionalized form of government that has elevated some federating States to an enviable height in the relations with other Nations. It is a form of government that has stabilized the politics and economy of the United States, Canada, Australia, India and Belgium. In Nigeria, Federalism as a form of government has been unable to fully impact on the Nigeria's national development. Nigerians have persistently sought for a reform of the quasi federalism that is practiced in Nigeria. The practice of federalism can hardly be distinguished from unitary form of government in the Nigerian case. Our inability to conform to the principles and tenets of federalism, where each level of government must be coordinate and independent of one another, is having an adverse effect on our nation building, political and economic stability and the determined effort to fight pervasive corruption in Nigeria.

Drawing from the practice of federalism, in the developed western Countries, it is believed that, its practice in Nigeria can be strengthened to have a positive impact on our national development. Nigeria is a diversified country, with most states having the potential of self-sustenance. Her diversity and natural endowment have not been explored to strengthen her national development, and place her in a true and genuine position to become the cynosure of emerging global economies in the year 2020 and beyond. 
There is no significant feature in Nigeria that shows the dual sovereignty principle of two coordinate levels of government according to Kenneth $\mathrm{C}$. Wheare's theory of federalism. This lack of sovereignty of the state governments has hampered them from taking initiatives that will sustain and advance their economies and the welfare of their people. States in Nigeria depend on federal allocation of funds for survival without any independent entrepreneurial adventures. The revenue allocation formula among the states has continued to be disputed.

One striking fundamental issue is that states in Nigeria are not created by their ability to sustain themselves and people through her natural and human resources endowment. The economy of the states is not self-sustaining, rather federal allocation of funds are shared to all the States to sustain them. This has contributed to a lack of effective competition among the states' economies. The states' become less resourceful and enterprising; whether they work hard or not at the end of the month, there must be federal revenue to allocate. This practice is a deterrence to effective competition and development.

This paper aims at affirming the goodies of federalism; strengthen the practice of federalism in Nigeria, and to contribute to her national development. The paper delves into the concept and evolution of federalism; take a critical look at the nature of Nigeria's federalism, its missing link, and using Kenneth C. Wheare's concept of federalism to strengthen federalism in Nigeria towards sustained national development.

\section{Conceptual Clarification}

A Federal system is one in which the powers of government are divided between a central government and regional governments of some kind, with each level having some independence of action in exercising their powers (Monan, 1972). The basic formal division of powers cannot be changed except by mutual consent. Federalism is further defined as "the theory or advocacy of federal political orders where final authority is divided between sub-units and the centre" (Onah, 2006). According to Jellinck in (Mbachu, 1997) a federal state is a sovereign state formed out of several states; the power of former being derived from the states which compose it and to which latter are bound together as to form a political entity. It is an association of states, which as a result formed the institution of a sovereign power superior to the associated states but in which however the latter participate. A Federal government is a form of government in which governmental powers are by the common sovereign distributed between a central government and local governments, each being supreme within its own sphere (Aruego and Aruego-Torres, 1981).

Graham Smith in (Ogu, 2011) argues that federalism can be considered as an ideology which holds that the ideal organization of human affairs is best reflected in the collaboration of diversity through unity. Elazar in (Ogu, 2011) defined federalism as a system of political organization uniting separate states or other units in such a way as to allow each to remain a political entity. A federal system which differs from other methods of organizing states is being based on a contractual agreement by separate government to share power among themselves.

According to Ayakeme (2005), Wheare defined federalism as a constitutional arrangement in which law making powers and functions are divided between Central and State governments in such a way that each, within its respective sphere of jurisdiction and competence is equal, independent and coordinate, to the extent of the federating states voluntarily surrendering some functions exigent on perceived capacity and desire to a central government for their collective good.

This paper adopts the meaning of federalism as propagated by Kenneth Wheare. It is a distribution of powers between the Central and the Regional governments, with each level having some independence of action in exercising its powers.

National Development: Lawal and Oluwatoyin (2011) describe national development as the overall development or a collective socio-economic, political as well as religious advancement of a country or nation. However in this paper, national development will refer to the ability of a country or countries to improve the 
social welfare of the people, by providing social amenities like quality education, potable water, transportation, infrastructure, medical care, etc.

\section{Evolution of Federalism}

The concept of federalism originated from the ideas of intergovernmental relations which date back to the Greek civilization, when efforts were made to describe the legal relationships between the Delian league and the City States (Mogi, in Ifesinachi 2007). The system of intergovernmental relations was used by the Italians of the middle Ages; and also in the development of the Swiss Confederation from the $13^{\text {th }}$ century. The ideas of federalism were also known to have influenced experiments in governmental organization in the Western hemisphere in the scattered islands of the Caribbean which by the 1680s have developed a form of federal council legislating in matters of common concern.

Jean Bodin was noted as the first advocate of modern federalism, followed by Otto Cosmanus, Hugo Grotius and others. These writers according to (Mogi, in Ifesinachi 2007), view federalism as a voluntary form of political union, either temporary or permanent, of independent authorities, for special common purposes such as defense against foreign powers for the interests of trade and communications or for other reasons.

It was in 1787 that the American constitution introduced a new concept of federalism, which emphasized contact at the governmental level between participating units and among the citizens of the different units. The study of contemporary federalism is traceable to the work of Wheare (1960) in which he sees the federal principle as the method of dividing powers so that general and regional governments are each within a sphere coordinate and independent.

\section{Features/ Characteristics of Federalism}

To Mbachu( 1997 ) there are three major characteristics of federalism. They are:

- Distribution of Power;

- Supremacy of the Constitution; and

- Supremacy of the Judiciary

King in (Ogu, 2011) noted four essential features of federalism as:

- Its representation is preponderantly territorial

- This territorial representation is characteristically secured on at least two sub-national levels which he refers to as local and regional governments.

- The regional units are incorporated electorally or perhaps otherwise, into the decision procedure of the national center.

- The incorporation of the regions into the decision procedure of the centre can be altered only by extraordinary constitutional measures, not, for example, by resort to a simple majority vote of the national legislature or by the autonomous decision of the national executive.

Of all four features mentioned above, King sees the last point about legislature entrenchment of the rights of the regions as the truly distinctive feature of federations.

Odion (2011) noted the basic tenets of Federalism according to Wheare as:

- There must be at least two levels of governments and there must be constitutional division of powers among the levels of governments.

- Each level of government must be co-ordinate and independent.

- Each level of government must be financially independent. He argued that this will afford each level of government the opportunity of performing their functions without depending or appealing to the others for financial assistance.

- There must be Supreme Court of the independent judiciary. He argued that in terms of power sharing, there is likely to be conflict hence, there must be independent judiciary to resolve the case. 
- In terms of the amendment of the constitution, no level of government should have undue power over the amendment process.

He maintained that, once a country is able to satisfy these conditions, such country is said to practice federalism.

\section{Evolution and Nature of Nigeria's Federalism}

Nigeria's federalism can be traced to 1914 when the Northern and Southern protectorates of Nigeria were amalgamated though with unitary form of administration. Thereafter, governmental powers started to be shared between the central government headed by the Governor-General and the governments of Northern and Southern protectorates headed by the lieutenant Governors. With the existence and recognition of the two autonomous parts of Northern and Southern provinces, the administrative system of Nigeria wore an outlook of a federation.

Sir Authur Richards's constitution of 1946 created three regions namely: the Northern region, Southern region and the Eastern region which gave more support to the emergence of Nigeria as a federal state. The Macpherson constitution of 1951 reinforced federalism in Nigeria. The constitution appointed lieutenant Governors to head these three regions and granted legislative power to the legislative and executive councils that were established. The Lyttleton constitution of 1954 (Odion, 2011) removed the final shade of a unitary government from Nigeria by establishing a true federal state in the sense that it shared powers between the central and the regional governments. To avoid constitutional conflicts that might arise between the central and regional governments, a supreme court was established to handle such conflict.

Odion(2011) gave an analysis of the evolution of Nigeria's federalism based on three fundamental reasons:

a) The British deliberately imposed the federal system on Nigeria in order to maintain a neo colonial control of the country after independence. Since federalism is more or less an evidence of some form of disunity, political weakness and uneven economic development, the British deliberately wanted to keep the federating units in other to meddle in the internal affairs of Nigeria to their own economic and political advantage after they have granted her independence.

b) The second aspect emphasizes the fact that historical and geographical factors determined the political evolution of Nigeria. Nigeria being a culturally variegated country could not have been governed from one centre. This interpretation is much more objective than the former. But it must be pointed that while the historical and geographical factors did not determine the shape and form of the federation that the British helped to create in Nigeria.

c) It was not a question of a country that was originally unitary, being broken into federating units, but of formerly totally independent kingdoms, Empires, nations and autonomous communities being brought together, and ending up in a federal union.

It is pertinent to mention here that just like the thirteen America colonies were autonomous of each other, so were the federating units of Nigeria namely: Eastern, Western and the Northern regions were autonomous of each other before the independence of Nigeria in 1960. The Eastern and Western regions were granted autonomy in 1957, while the Northern Nigeria was granted autonomy in 1959. The British colonial masters crafted federalism as a form of government that soothes the multi ethnic, linguistic and culturally diverse Nigeria. Nigerian nationalist leaders felt that the diversity of Nigeria will be a strong positive trait that can propel her economy hence; they supported the unity of Nigeria as a Country. Unlike in the case of Rhodesia and Nyasaland which was in the situation of Nigeria, they chose to divide or split themselves to different countries that made up the states of Zimbabwe, Zambia and Malawi respectively.

A critical view of Nigeria's federalism will reveal that, we are not practicing federalism. Odion(2011) observed that, it is surprising that Nigeria only operates federalism on paper. The federal structures have never existed in Nigerian society. Odion attributed the reason to the intervention of the military in 
government. In Nigeria, the federal government assumes superiority over the state government. This may have been precipitated by the military government that always interrupted democratic regimes. By the principle of federalism, according to Wheare, the relationship between the federal and states government must be co-ordinate and independent of one another. In Nigeria, the states rely on the federal government for survival instead of being independent and making contributions from the states to the federal government.

Resource aggregation is a major shift from the practice of federalism. In federalism; before the formation of federalism, the regions, states or federating bodies are autonomous. They have a definite territory, resources, government, and culture before conceding to a common union. They own their naturally endowed resources that they ought to control, manage and pay taxes or certain percentage of their income to the federal government. In Nigeria, the states are being dispossessed of their resources. The resources are owned and managed by the federal government. This practice is unacceptable, and it is a contributory factor to pervasive corruption in Nigeria. The states which own the resources, in their respective states, should be in control of the resources. It should manage it and pay levies or taxes to the federal government.

Financial autonomy is another area that Nigeria's federalism is derailing. In Nigeria, States are not created due to their viability, rather due to their ability to collect monies from the federal government. States here are not challenged to develop their economies. They are not competitive rather whether they labour or not, at the end of the month, they get federal allocation.

\section{The Missing Link of Nigeria's Federalism}

Due to the divergent approaches to federalism by different proponents and advocates, it is sometimes difficult to establish the missing link of Nigeria's federalism. Wheare provided the legal framework of what constitutes federalism (federal constitution). Other writers have adopted divergent approaches to federalism. Livingstone (1968) looked beyond the surface of social diversities that the constitutional division of powers is supposed to convey. Riker (in Ifesinachi, 2007) focused on the bargaining and integrative roles of capitalist parties. Etzioni (in Ifesinachi, 2007) looked at the process of unification and interactions among the major political leaders. We can deduce that, federal instrumentalities can be found in several forms of political system ranging from centralized to decentralize and even to a loose structure of supranational cooperation. The implication here is that, the dividing line between federal and non-federal systems cannot be sharply drawn.

However, for the purpose of this study, Wheare's ideas, a noted contemporary advocate of federalism, shall be used to identify the missing link in Nigeria's federalism.

- Each level of government in Nigeria is not co-ordinate and independent.

The federal government owns and controls all the resources in the country. The states are being deprived of their right to own and have control over their resources. This makes the States to be dependent on the federal government for allocation of funds for their survival. Nigeria's federalism is built on injustice and falsehood. This deters genuine competitiveness among the states.

- Each level of government is not financially independent. This will enable States have the opportunity of performing their functions without depending or appealing to the Federal government for financial assistance.

- The functions of the federal government are too clumsy and conflicting. The federal government functions need to be limited to defense, external affairs, Currency regulation and communication. In the case of Nigeria, the Federal government is in charge of virtually every function of governmental affairs. For instance, there is a Minister of Education, a junior Minister, and Commissioners of education at the State levels; this is a duplication of functions. The federal government should have her sphere of operation while cooperating with the state governments. It should allow the state governments to be independent.

- States are not created based on their viability or ability to sustain herself. Rather they are created to be sponsored by federal government allocation of funds on monthly basis. This has led to a 
lopsided revenue allocation formula that has been constantly criticized by the states that generate the largest portions of the allocated funds. This situation that has led to their popular advocacy for resource control. The wealth endowed on some states is being monopolized by the federal government. This situation has inhibited free market competition among the states of the federation.

\section{Stenghtening Nigeria's Federalism for National Development}

National development, being the ability of a country or countries to improve the social welfare of their people, by providing social amenities like quality education, potable water, transportation, infrastructure, medical care, etc., can be facilitated by the efficiency of an institutional form of government. Federalism has been acclaimed to be the best institutional form of government that sooths country with renowned diversity. It has boosted the United States of America, Australia, Canada etc. Its efficiency cannot be doubted, hence if the practice of federalism is strengthened in Nigeria, there is, no doubt, that, it will precipitate/facilitate national development.

One of the ways of strengthening federalism in Nigeria is to ensure that States are being created due to their ability to sustain themselves, and not based on federal government allocation of funds. In Nigeria States are not created due to their propensity to sustain themselves, rather due to federal government allocations. This does not conform to the principles of federalism. This, to a large extent, does not encourage positive commercial competition among the States. It will even affect their creativity and productivity because whether they work or not, federal government must allocate some funds to the States at the end of every month from the National account.

All the levels of government should be coordinate and independent. The federal government in Nigeria is too powerful. It does not coordinate with the states as equals, neither are the states independent in any sphere of her activities. The States need to be autonomous in most of her activities. This will give more time to the Federal government to attend to limited matters of great importance to national interest. It will reduce the clumsiness of government functions, structures and ministerial conflicts and reduce the cost of governance.

This paper in principle supports the creation of State Police to manage the internal security of the States. This will limit law enforcement agents to their terrain which they are very conversant with State Police will impact positively on crime control and prevention. However, considering the wobbling status of sustainable democracy in Nigeria, it is not timely to constitute a State Police because, there is the fear that due to lack of maturity of our political culture and her politicians, those in power can use them to harass and intimidate their political opponents, and even use them to rig elections. Hence this paper supports its implementation in the next sixteen years.

Each State should have absolute control of her wealth and resources. They can partner with the Federal government in the exploration and exploitation of any resources within their territorial jurisdiction. On the contrary States should control their resources and pay certain percentage of taxes to the Federal government. This is one of the real attributes of Federalism. States must be independent in the ownership of their resources. In Nigeria's Federalism, the reverse is the case. The Federal government owns all the resources in any part of Nigeria. The States do not have right of inheritance and even to inherit their natural endowment. This has enhanced the conspiracy of the elites to propagate corruption, appropriate enough wealth of the nation to themselves at the federal level. This has contributed to less productivity of the States, since they must get national allocation of funds from the Federal government. The States are not competing among themselves; hence Nigeria is importing most all her needs from abroad. States should be allowed to control their resources and pay certain percentage of taxes to the Federal government.

Ethnicityis a major problem in Nigeria that impacts negatively on our Federalism, unity and National integration. Most Nigerians are more loyal to their tribes than they are to Nigeria. Nigerians are too protective 
of their tribal interest over national interest. No Nigerian language should be adopted as a national language. Nigeria should remain secular both in religion and in Language. English language should be adopted as our lingua franca. There is great need for us to detribalize Nigeria. Any attempt to recognize one language will be considered as an attempt to encourage ethnicity, which is a strong factor that affects our unity and national integration.

Strengthening of the Nigerian Constitution to reflect our federal status will go a long way to strengthen our federalism, and enhance our national development. The constitution which provides for federalism is practiced as a unitary government. There is no proper delineation of the powers of the Federal government from the power of the States government. The concurrent and exclusive list that specifies and separates the functions of the level of government, allocates all the powers in both list to the federal government. The federal government functions should be properly delineated and limited to: defense, foreign affairs, currency, etc. The organs of government instead of acting as a check on one another, they operate as a clique of the ruling class to compromise among themselves.

Two party systems should be imposed. This will reduce tribal and ethnic sentiments and expedite national integration in Nigeria.

Strengthening the Judiciary for independent and effective performance.The Judiciary should be strengthened for independent and effective performance: A special department comprising the operatives of the State Security Services and Judiciary staff should be constituted to handle cases of corrupt practices; with a special Court to be presided by a Justice attached to it. More lawyers should be recruited int the judiciary for efficient and timely dispensation of justice in all her departments. This will boost the practice of federalism and impact on our national development.

\section{Conclusion}

The British colonial masters crafted federalism as a form of government that soothes the multi ethnic, linguistic and culturally diverse Nigeria. Nigeria nationalist leaders felt that the diversity of Nigeria will be a strong positive trait that can propel her economy hence; they supported the unity and federalization of Nigeria as a country.

Federalism has been acclaimed to be the best institutional form of government that soothes a country with renowned diversity. It has boosted the United States of America, Australia, Canada etc. Its efficiency cannot be doubted; hence the need to strengthen the practice of federalism in Nigeria in other to facilitate national development.

The practice of federalism in Nigeria is a distortion of the accepted and nature of federalism as conceived by our Nationalist elites. The incessant military incursion into Nigeria's governance has contributed immensely to the distortion of the practice of federalism as propounded by Wheare and the original concept of Nigeria's federalism. Military regime and dictatorship in general are known for centralization of power. Before the advent of military regime in Nigeria, federalism was practiced as conceived by our nationalist leaders. Since military incursion into governance in Nigeria, the relationship of the federal government and other levels of governments have not been coordinate and independent. The independence of the states, resource control and revenue allocation have been so distorted to the disadvantage of the states, national integration and national development.

Nigerians are aware of these distortions but, the ruling elite seem to be favoured by such distortions hence, they have compromised to loot the treasures of the nation and damn the lopsidedness of the country. With the clamour for constitutional amendment, there is great hope that the people will come out boldly to right the wrongs. There is a limit to accepting the practice of unitary system in place of Federalism. Nigeria's federalism can be strengthened to be as efficient as that of other developed countries, if her people are serious for a positive change. 
The practice of federalism is very appropriate for a diversified country like Nigeria. Her ruling elite should endeavour to restructure the quasi federal system that is capable of truncating the unity of the country. There are great advantages to our national development if we can strengthen the practice of federalism, by respecting the independence of the federating units, allowing them to control their resources and their internal security.

\section{Recommendation}

Federalism is the best form of institutional form of government that sooths Nigeria due to her ethnic, cultural, language, religious and geographic diversities. Its practice in Nigeria can be strengthened to facilitate her national development and integration. Nigeria's constitution should be amended to reflect the following: Merging of states, states are being created due to their ability to sustain themselves, and not based on federal government allocation of funds. States should be merged so that they can sustain themselves with their natural endowments both natural and human resources. All the levels of government should be coordinate and independent. The concurrent and exclusive list should limit the powers and functions of the federal government to Foreign affairs, defense, currency regulation, etc. This paper in principle supports the creation of State Police to manage the internal security of the States. Each State should have absolute control on her wealth and resources and make contributions to the federal government. The practice of federalism should be complemented with two party systems. This will reduce tribal and ethnic sentiments and expedite national integration.

\section{References}

Aruego, J.M and Aruego-Torres, G.E (1981) Principles of political science, Philippines, University Book Supply. Ayakeme, W.(2005). "Who is afraid of true federalism?" Published in the ThisDay, July $19^{\text {th }}$. P.16.

Monan, R (1972) American government: policy and process. Richard Longaker (Ed.) Boston, Houghton Mifflin Company. Onah, F.E (2006) Fiscal federalism in Nigeria. Nsukka, Great Express Publishers.

Mbachu, O.I (1997) The anguish of federalism in Nigeria. Nigerian politics. Ndoh, C.A and Emezi, C.E (Ed.). Owerri, CRC Publication.

Odion, I.R (2011) A critical assessment on Nigerian federalism: path to a true federal system. A paper presented at the $4^{\text {th }}$ annual national conference, I.B.B hall F.C.E (T) Potiskum, Yobe state.

Ogu, M.I (2011) Federalism as an essentially contested concept: A discusses. Nigeriaworld senatorclue@yahoo.com Ifesinachi, K(2007) The concept and practice of federalism. Onuoha, J and Nwanegbo, C.J. Theory and Practice of Intergovernmental relations in Nigeria, Enugu, Quintagon Publisher 